\title{
Lexical and Syntactic Competency through Language Camp Activities Based on Multiple Intelligence Approach
}

\author{
Sutthisan, S. $^{1}$ \\ ${ }^{1}$ Department of English, Faculty of Humanities and Sciences, Thepsatri Rajabhat University, \\ Mueang, Lop Buri, Thailand, 15000 \\ Corresponding email: sutthisan@hotmail.com
}

\begin{abstract}
The attempts of the present research were 1) to investigate the students' problems in terms of lexical and syntactic usage in Language camp prior to the implementation of the activities based on multiple intelligence approach 2) to develop the students in terms of lexical and syntactic used in Language camp and 3 ) to compare the students' learning achievement in terms of lexical and syntactic used in Language camp before and after implementing the activities based on multiple intelligence approach. The research sample, obtained by a purposive sampling technique, comprised 52 third-year students enrolled in Language Camp for English Skill Development course in the $2^{\text {nd }}$ semester, Academic Year 2017. The research tools used in the study comprised of pre-and post-test, activities based on Multiple Intelligence approach, and standardized interview. The obtained quantitative data were computed by means, standard deviation, percentage, and independent sample t-test whereas the content analysis was done to elicit the qualitative data. The findings indicated that the students' problems of lexical and syntactic usage were categorized into two main issues: the confusion of using vocabularies and sentences and incorrect sentence orders. The results from the comparison before and after implementing the activities based on multiple intelligence approach revealed statistically significant differences at the .01 level. The students' achievements were considerably improved after learning through the activities based on multiple intelligence approach and could employ each lexical and syntactic category with more confidence when retaking the exam.
\end{abstract}

Keywords: development; lexical and syntactic usage; multiple intelligence approach

DOI: $10.20961 /$ ijpte.v\%vi\%i.25146

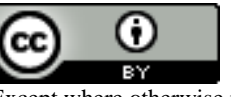

Except where otherwise noted, content on this site is licensed under a Creative Commons Attribution 4.0 International License. 


\section{INTRODUCTION}

Thailand nowadays is in the era of English learning management development. Students should have opportunities to learn English in schools. According to Bureau of Academic Affairs and Educational Standards office of the Basic Education Commission, Ministry of Education (2008), the policies of Thai Ministry of Education point out the fact that students from Grades 1 to 12 must study English, which has a very important role for communicating with other people around the world and receiving information from worldwide. Most Thais believe that lexicon is the most important thing to learn English, and syntax is also essential when using in all skills. Salungsuk, Toonthong and Sriraksa (2013) mentioned that the key factor of learning and teaching English is vocabulary that is used in an academic field. If learners know very few words or do not understand them at all, they cannot understand reading materials, and that may affect learning other skills. Moreover, Rezeq (2014) said that vocabulary helps students develop the main English skills which are listening skill, speaking skill, writing skill and reading skill. Larsen-Freeman (1986) suggested that vocabulary teaching has its importance since it is an essential part of learning a new language. Different methods treated vocabulary teaching differently.

A teaching method that has been studied by many researchers and perceived as one of the best strategies to develop students' lexical and syntactic usage is an activity. Gardner (1993) suggested that the theory of Multiple Intelligences provides a new approach to teaching and learning process. There are eight types of multiple intelligences: Linguistic intelligence, Intelligence logical - Sports, Visual Intelligence, Intelligent physical - motor, Musical Intelligence, Interpersonal Intelligence (social), Personal Intelligence and Natural intelligence. Interpersonal Intelligence is one of the intelligences that has been utilized in language teaching. Hussen (2010) explained that the activities based on social intelligence included role-playing games and collaborative learning-group games. Many researches state that most students improved their lexical and syntactic usage through Gardner's theory. According to Roekmuang (2009), her research was to develop English Vocabulary Learning of Grade four students, and it was found that the students' retention in learning English vocabulary were higher than 70 percent. Moreover, most students were fond of learning English vocabulary through games. Sripramong (2004) said that the purpose of this experiment was to study the effect of using vocabulary games on the retention in learning vocabulary of Prathomsuksa five students in the second semester of 2003 at Assumption College Rayong. The findings revealed that the students' retention in learning English vocabulary was at a high level, and the grade 5 students were satisfied with the vocabulary activities. In addition, In Akçin's study (2009), the purpose of the study was to find out the effects of Multiple Intelligence Theory in teaching English vocabulary. Traditional vocabulary teaching techniques and vocabulary teaching 
techniques based on Multiple Intelligence Theory were compared in the study. Both of the two groups were required to take pre-tests at the beginning of the study. In addition, Multiple Intelligence Inventory was applied to the experimental group to identify their dominant intelligences and prepare classroom activities accordingly. The results of the study suggested that Multiple Intelligence Theory based on activities had a significant effect on achievement and retention of students' English vocabulary. According to the aforementioned studies, it can be noticed that activities can develop most students' lexical and syntactic knowledge. Kunakorn (1998) noted that playing games are suitable learning tools for promoting students' vocabulary learning development; in addition, they had a good attitude toward English, and they could recognize English vocabulary accurately and extensively. Wright (2005) agreed that games are used to assist young learners during their language learning. They make classes entertaining and sustain effort and interest. There are many kinds of activities based on multiple intelligence approach. However, activities or games the teacher choose are supposed to be suitable for students. Bakhsh (2016, p.125) stated, "though games are very popular among young learners, they should not be overused. They should be chosen appropriately to students' level, interest, and context. Furthermore, it must be concerned with the presented topic and vocabularies. Any game can be effective when it is used suitably to the topic and is controlled by wise and skilled teacher."

As a lecturer at Thepsatri Rajabhat University who taught Language Camp for English Skill Development course, the researcher noticed the problem that a large number of students could not use lexical and syntactic knowledge properly in this course. They needed to improve their lexical and syntactic usage in order to become more successful when using vocabulary and structures. This research aimed to develop their lexical and syntactic usage through games, based on social intelligence activities, which was one of the eight intelligence skills.

The purposes of this research were 1) to study the students' problems in terms of lexical and syntactic usage in Language camp prior to the implementation of the activities based on multiple intelligence approach 2) to develop the students in terms of lexical and syntactic used in Language camp and 3) to compare the students' learning achievement in terms of lexical and syntactic used in Language camp before and after implementing the activities based on multiple intelligence approach.

\section{METHODS}

The present study was done by an experimental method. The samples used were undergraduate students who were aimed to develop their lexical and syntactic usage after the implementation of gamification activities.

In the early stages of the study, the students' problem related to lexical and syntactic usage were elicited by using pretest and standardized interview 
respectively. After that, the results were computed and analyzed in order to use as framework to develop the gamification activities based on multiple intelligence approach, and lesson plans.

The samples used comprised of 52 third-year students majoring in English Education, who enrolled in of Language Camp for English Skill Development Course, the $2^{\text {nd }}$ semester, 2017 Academic Year, the Faculty of Humanities and Social Sciences of Thepsatri Rajabhat University.

The research instruments were as the followings:

1) A pre- and post-test comprised 40 writing items with regard to 7 subcategories of language of camp, including general instructions and request, organizing which are grouping the campers, classroom arrangement, things required for the activity, organizing the games, praising, reprimanding and evaluating, greeting and farewells, interpersonal exchanges, and miscellany. Before the developed tests were given to the samples, the tests were distributed to the three language experts who were English native speakers, piloted with 10 fourth-year students majoring in English Education with a reliability of 0.76 .

2) Activities based on multiple intelligence approach consisted of 7 subcategories of language of camp, including general instructions and request, organizing which are grouping the campers, classroom arrangement, things required for the activity, organizing the games, praising, reprimanding and evaluating, greeting and farewells, interpersonal exchanges, and miscellany. Language of camp was comprised of a lesson plan for instructor, contents, and activities, so the students could practice more with both contents in Language Camp for English Skill Development textbook and activities that prepared by instructor and $4^{\text {th }}$ year English Education students in the English Education Department, the Faculty of Humanities and Social Sciences, Thepsatri Rajabhat University. The multiple intelligence gamification activities were designed based on the basis of the obtained results from pretest and standardized interview. The contents of the activities were tested and proofed by the three English native speakers for its feasibilities e.g. appropriateness and accuracy. After that, the contents were revised and improved based on the obtained advices from the experts to gain more its validity and reliability before distributing to the experimental samples.

The activities that the researcher used were as follows:

1. Word Hunt Game

2. Build a sentence Game

3. Matching sentences and meaning Game

4. Command game

3) Standardized interview was done with the top-ten students who received the highest scores and ten students who received the lowest scores after the implementation of the activities. 
The quantitative data were analyzed by means, standard deviation, percentage, and T-test whereas the content analysis was conducted to analyze the qualitative data obtained from the interview.

1) Percentages were used to find out how well the students did in their pre-and post-test. The test score results were divided in to 4 levels and graded in the following criteria: $90 \%$ or above referred to as 'excellent', $70-89 \%$ as 'good', 50-69\% as 'fair', and below 50\% as 'need improvement'.

2) Paired sample dependent t-test was employed to analyze the students' lexical and syntactic usage before and after the implementation of the activities.

The independent variable of this research was the learning lexical and syntactic usage through activities and the dependent variable was the learning achievement of the students' lexical and syntactic usage. The experiment took four weeks altogether; the first week was testing and interviewing the students to study their problems of using lexical and syntactic knowledge. From weeks two to three, the students were studying by using the activities to learn the Language of camp of 7 subcategories including general instructions and request, organizing which are grouping the campers, classroom arrangement, things required for the activity, organizing the games, praising, reprimanding and evaluating, greeting and farewells, interpersonal exchanges, and miscellany. Then, the post-test was taken by the students in week four.

\begin{tabular}{|c|c|}
\hline Pre-test \& Interview & \\
\hline $\begin{array}{l}\text { Independent Variable } \\
\text { Implementation of } \\
\text { the activities related to } 7 \\
\text { subcategories } \\
\text { - General instructions and } \\
\text { request } \\
\text { - Organizing } \\
\text { - Praising } \\
\text { - Reprimanding and evaluating } \\
\text { - Greeting and farewells } \\
\text { - Interpersonal exchanges } \\
\text { - Miscellany }\end{array}$ & $\begin{array}{l}\text { Dependent Variable } \\
\text { Higher Learning Achievement in } \\
\text { terms of lexical and syntactic } \\
\text { usage covering: } \\
\text { - General instructions and } \\
\text { request } \\
\text { - Organizing } \\
\text { - Praising } \\
\text { - Reprimanding and evaluating } \\
\text { - Greeting and farewells } \\
\text { - Interpersonal exchanges } \\
\text { - Miscellany }\end{array}$ \\
\hline Post-Test \& Interview & \\
\hline
\end{tabular}

Figure 1: Research Framework 


\section{RESULTS}

\section{Students' Problems In Lexical And Syntactic Usage}

From the research study, it was found that, in terms of their pre-test scores, seventeen students (32.69\%) failed, their pre-test scores were lower than 50\%, nineteen students (36.54\%) had fair scores, they obtained the score with 50-69\%, eleven students (21.15\%) had good scores with 70-89\%, and only five students were in excellent level with $90 \%$ and higher. It seemed surprising that only sixteen $3^{\text {rd }}$ year English Education major students' scores were in good and excellent level, so that meant many of them had problems in lexical and syntactic usage. As a result of the pre-test, interview was conducted in order to detect the problem of lexical and syntactic usage of English. According to the results of the students' interview prior to studying through activities, it revealed that the two problematic aspects that influenced students' reading ability somewhat low were as follows:

it was concluded that the two major problem issues that made students' reading ability somewhat low were as follows:

1) Most of the students were inadequate with necessary English lexicon when using in the Language Camp, also they got confused when they had to form English structures. Besides, some of them made lexical and syntactic mistakes.

2) From the students' reflection, they said that using broken English to communicate with other people is possible as long as the interlocutors understand intended messages. Moreover, they thought that sometimes using English structures correctly was so difficult.

After obtaining the results from the students' interview, the researchers tried to find out a way to teach more attractively and easily by using activities so that the students could use the games to review the lessons by themselves after classes.

\section{A Comparison of the Students' Learning Achievement in Terms of Lexical and Syntactic Usage}

In order to answer the research question three, the students', leaning achievement before and after the implementation of English lexical and syntactic usage activities was shown in the Table 1 below:

Table 1 Students', learning achievement in terms of lexical and syntactic usage

\begin{tabular}{ccccccc}
\hline Number of Students & \multicolumn{1}{c}{ Pre-test } & \multicolumn{2}{c}{ Post-test } & t-test & Sig \\
\hline & $\mathrm{x}$ & SD & $\mathrm{x}$ & SD & & \\
\hline 52 & 10.87 & 4.93 & 16.40 & 2.93 & -5.53 & $000 *$ \\
\hline
\end{tabular}

As presented above, the Table 1 revealed the comparison of the students' learning achievement before and after implementing English lexical and syntactic usage by activities based on multiple intelligence approach obtained by the third year English Education students who enrolled in Language Camp for English Skill Development course. In the overall, the mean scores from the post-test (16.40) 
were significantly higher than the pre-test (10.87). Also, there was statistically improved between pre-test and post-test at the .01 level. According to the results, it was indicated that the implementation of gamification activities based on multiple intelligence approach can improve the students' achievement in terms of lexical and syntactic usage.

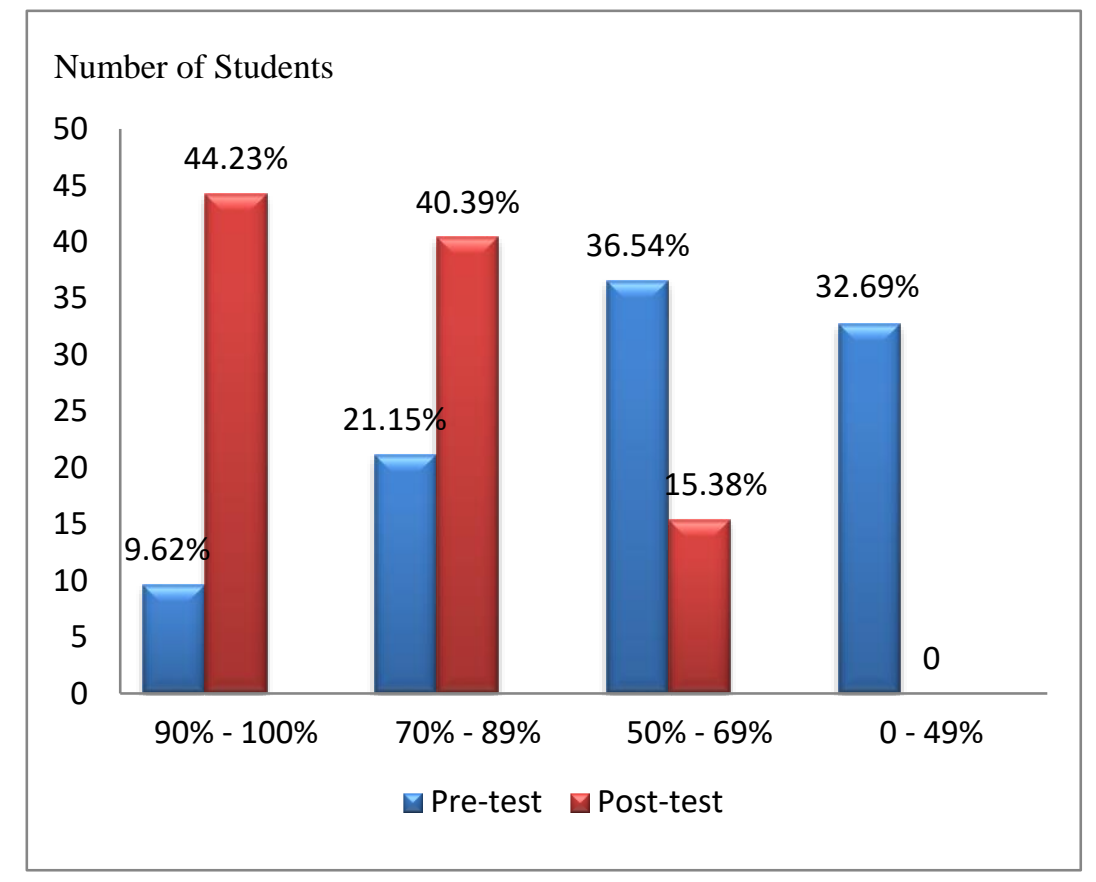

Figure 2 Results of leaning achievement before and after studying English lexicon and syntax through activities

Figure 2 showed the results of the pre-test and post-test scores on the students' leaning achievement before and after playing games and doing the activities. According to the results, it was found that the average rate of the learning achievement of the students after learning through games and activities was higher than the prior scores before studying through games and activities. All the students passed the test after studying through games and activities. Moreover, most students' scores were significantly higher after learning through games and activities. In terms of their English lexical and syntactic usage scores, at first in the pre-test scores, there were only five students (9.62\%) in an excellent level, but after learning through games and activities twenty-three students (44.23\%) got excellent post-test scores, eleven students (21.15\%) had good scores in pre-test. However, twenty-one students (40.39\%) got good scores in post-test, nineteen students (36.54\%) with fair scores but after they learning through games and activities, there were only eight students $(15.38 \%)$ at a fair level. There were seventeen students $(32.69 \%)$ who failed the pre-test exam; however, gladly, there were no students who failed in post-test exam after learning through games and activities.

After the students' post-test scores came out, 10 students who got the highest posttest scores were selected for the interview regarding the lexical and syntactic 
usage through games and activities taught in class. All of them understood how to use lexical and syntactic knowledge better, they were comfortable and more confident to use syntactic. In addition, they thought it was easier to use the vocabularies and arrange the sentences in their mind. They also said that they could keep the lexicon in their brain longer. Furthermore, all of them agreed that learning vocabulary and structures through activities is a great way to improve not only lexical and syntactic usage but also their all English skills.

\section{DISCUSSIONS}

From the results of students' leaning achievement before and after studying English lexicon and syntax through activities in relation to studying the Language of camp of seven subcategories including general instructions and request, organizing which are grouping the campers, classroom arrangement, things required for the activity, organizing the games, praising, reprimanding and evaluating, greeting and farewells, interpersonal exchanges, and miscellany of the third year students majoring in English Education, the Faculty of Humanities and Social Sciences, Thepsatri Rajabhat University, the students' post-test scores were significantly higher than the pre-test scores at the .01 level. It can be seen that the research results were related to the study of Roekmuang (2009). She said that her research was the objective of this master project which was to develop English vocabulary learning of fourth grade students, and it found that the students' retention in learning English vocabulary game were higher than 70 percent. Moreover, most student fond of learning lexical though games. Moreover, Sripramong (2004) said that the purpose of this experiment was to study the effect of using vocabulary games on the retention in learning vocabulary of Prathomsuksa five students in the second semester of the 2003 at Assumption College Rayong. The findings revealed that: the students' retention in learning English vocabulary games was at high level and the students of Prathomsuksa 5 were satisfied with the vocabulary activities.

Nonetheless, both of the researches did not emphasize syntactic usage, which were considered as essential to students' factor to use in Language of Camp. It can be said that this present study could be used as guidance for those who are interested in creating activities focusing on syntactic usage for their students.

Based on the activities used in this research, it is reasonable to say that Multiple Intelligence theory brings higher motivation both instructor and students. In addition, Multiple Intelligence theory proved to be more helpful instructor in teaching with variety activities, materials, and methods which needed in the daily lessons plan and students in achievement of learning vocabulary and syntactic usage. 


\section{CONCLUSION}

Overall, the results of this study indicated that the third year students majoring in English Education improved their English lexical and syntactic usage after learning through activities based on Multiple Intelligence theory. The results of pre- and post-test showed that their lexical and syntactic usage were significantly different. Moreover, there were no students failed after studying through activities based on Multiple Intelligence theory. Prior to the implementation, seventeen students did not pass however only five students were in excellent level in the pretest, but after they learned through activities based on Multiple Intelligence theory, $100 \%$ of the students passed the exams. Moreover, twenty-three students (44.23\%) got excellent post-test scores. After the experiment, it was found that there were many factors that were possible for this case. The students impressed learning through activities. At first they thought learning lexical and syntactic usage in Language of Camp were very difficult to understand. However after the researcher changed the way of teaching from only reading and doing exercises to activities based on multiple intelligence. They have been fully willing to participate in activities. These factors may have affected their ability and willingness to do the test; in consequence, the results will affect the outcome of the test.

From the research above, it is quite clear that the multiple intelligences and educational applications impact effectively on the learners. This research is based on teaching students by applying lessons with activities, so the suggestions on developing the third year English Education major students' lexical and syntactic usage were that the instructors should organize the learning management with multiple activities. The way of teaching should be interesting and easy to understand because it motivates several students' participation. Besides, before creating variety of activities, techniques or strategies based on Multiple Intelligence theory in any other English skills, the instructors should examine and interview the learners first so that the instructors will have a lot of information and know how much learning ability the students have and then the instructors can adjust the activities to be more suitable and enjoyable with the learners' ability. Furthermore, using different activities of multiple intelligence depend on the nature of learners' intelligence. That means the students will really improve themselves and get ready to apply their knowledge especially in lexical and syntactic usage into their education and daily lives in a suitable activities based on the multiple intelligence theory.

More areas with regard to lexical and syntactic usage not only in Language of Camp but also in other topics such as English for Business Correspondences, English in Classrooms, Contemporary English in Various Situations, etc. should be studied. Moreover, it would be useful and helpful for students in other English skills such as listening, speaking, reading and writing, etc. 


\section{ACKNOWLEDGEMENTS}

The researcher would like to express sincere appreciation to all those who assisted until the completion of this paper. In addition, special gratitude also goes to all the fourth year English Education major students, the Faculty of Humanities and Social Sciences at Thepsatri Rajabhat Univerisity for participating and assisting to create the activities. Without them, I could not have reached this goal. I am indebted to the third year English Education major students, the Faculty of Humanities and Social Sciences at Thepsatri Rajabhat Univerisity who were the research participants of this study for their hard-working and cooperation.

\section{REFERENCES}

Learning Indicators Based on English National Curriculum. (2008). Bangkok: Ministry of Education.

AKÇIN, S. (2009). The Effects of Using Activities Based on Multiple Intelligence Theory on 11th Grade Students' Learning and Retention of English Vocabulary. Dokuz Eylül Üniversites Egitim Bilimleri Enstitüsü,

Bakhsh, S. A. (2016). Using Games as a Tool in Teaching Vocabulary to Young Learners. English Language Teaching, 9(7), 120-128.

Gardner, H. (1993). Frames of Mind: the theory of multiple intelligences: Basic Books.

Hussen, S. S. (2010). Effect of using the activities of multiple intelligences to learn some basic skills in kata and level of harmonic behavior of the mentallyHandicapped, "Acceptors for learning. Procedia Social and Behavioral Sciences, 5, 1950-1955.

Kunakorn, S. (1998). A comparison of Prathomsuksa 1 Students' Math Learning Achievement and Retention Using Play \& Learn Method and Traditional Method. (Master's Degree), Burapa University, Chonburi.

Larsen-Freeman, D. (1986). Techniques and Principles in Language Teaching. Oxford: Oxford University Press.

Rezeq, R. S. A. (2014). The Effect of Using Multiple Intelligences on Developing Fifth Graders' Achievement of Vocabulary in the Gaza Strip. Al-Azhar University-Gaza

Roekmuang, B. (2009). Using Vocabulary Gamesto Develop English Vocabulary Learning Of Prathomsuksa 4 Students At Burarak School. (Master's Degree), Srinakharinwirot University,

Salungsuk, T., Toonthong, S., \& Sriraksa, P. (2013). A Comparison of Vocabularies Memorized Ability and Attitude Towards English Learning of Prathomsuksa 
4 Students Taught by Songs and Games. Paper presented at the Graduate Research Conference, Khon Kan University.

Sripramong, S. (2004). The Study of the Effect of Using Vocabulary Games on the Retention in Learning Vocabulary of Prathomsuksa Five Students. (MA), Srinakharinwirot University, Bangkok.

Wright, A., Betteridge, D., \& Buckby, M. (2005). Games for language learning (3ed.). New York: Cambridge University Press 
